\title{
Life Cycle of Vermicomposting Earthworms Eisenia Fetida and Eudrilus Eugeniae Under Laboratory Controlled Condition
}

\author{
Ali S* and Kashem MA \\ Department of Soil Science, Faculty of Agriculture, Bangladesh
}

Received: 㘹: October 25, 2018; Published: 制: November 08, 2018

*Corresponding author: Ali S, Department of Soil Science, Faculty of Agriculture, Bangladesh

\begin{abstract}
The study was initiated and reproductive efficiency of vermicomposting worms to see the growth, reproductive biology and life cycle of the vermicomposting earthworms (Eisenia fetida and Eudrilus eugeniae) at the lab Department of Soil Science during 15 February to 10 June 2018. Determination of cocoon production rate, hatching success, number of hatchling and growth of Eisenia fetida and Eudrilus eugeniae in the cowdung media was conducted with plastic containers. The experiment was designed under the single treatment cowdung with three replications. Clitellum development started earlier in $3^{\text {rd }}$ week of Eisenia fetida than Eudrilus eugeniae ( $4^{\text {th }}$ week). Number of cocoons produced per earthworm $(21.8 \pm 3.0)$, mean number of hatchlings from one cocoon (3.3 \pm 0.57$)$, hatching success rate (86.6\%) was recorded higher of Eisenia fetida.

Cocoon production of E. fetida was started to release cocoon on the $6^{\text {th }}$ week and Eudrilus eugeniae was started to release cocoon on the $7^{\text {th }}$ week. Cocoon production ceased after 12 week for Eisenia fetida and 9 week Eudrilus eugeniae. Maximum weights achieved per earthworm $(1116 \pm 16.4$ $\mathrm{mg}$ ), net weight gain per earthworm $(819 \pm 12 \mathrm{mg}$ ), growth rate per worm per day $(17.43 \pm 1.4 \mathrm{mg})$ were higher in Eudrilus eugeniae comparison to Eisenia fetida. The overall result of this study showed that better hatching success of cocoons and number of hatchling per cocoon were recorded by Eisenia fetida earthworm species.
\end{abstract}

Keywords: Eisenia Fetida; Eudrilus Eugeniae; Earthworms; Life Cycle

\section{Introduction}

Earthworms are macroscopic clitellate oligochaete annelids that live in soil. They are segmented worms, bilaterally symmetrical, with an external gland (clitellum) for producing the egg case (cocoon), a sensory lobe in front of the mouth (prostomium), and an anus at the end of the animal body, with a small number of bristles (setae) on each segment. They are hermaphrodite animals, and reproduction normally occurs through copulation and cross-fertilization, following which each of the mated individuals produces cocoons containing 1-20 fertilized ova. The resistant cocoons, which are tiny and roughly lemon-shaped, with shape differing between species, are usually deposited near the soil surface, except in dry weather when they are laid at deeper layers. Cocoons hatch after an incubation period that varies according to the earthworm species and environmental conditions. Hatchling earthworms, unpigmented and only a few millimeters in length on emerging from the cocoons, gain their adult pigmentation within a few days. Assuming favorable conditions, they reach sexual maturity within several weeks after emergence.
Mature individuals of most vermicomposting species can be distinguished easily by the presence of the clitellum, the pale or dark colored swollen band located behind the genital pores. The clitellum secretes the fibrous cocoon, and the clitellar gland cells produce a nutritive albuminous fluid that fills the cocoon. Earthworms display indeterminate growth and can continue to grow in size after completing their sexual development although they do not add segments. According to Reynolds and Wetzel [1], there are more than 8300 species in the Oligochaeta, of which about half are terrestrial earthworms. On the basis of their feeding and burrowing strategies, into three ecological categories: epigeic, anecic, and endogeic [2]. Endogeic (soil feeders) and anecic species (burrowers) live in the soil and consume a mixture of soil and organic matter, and thus excrete organomineral feces. Epigeic species of earthworms are litter dwellers and litter transformers; they live in organic soil horizons, in or near the surface litter, and feed primarily on coarse particulate organic matter. 
They ingest large amounts of under composed litter and excrete holorganic fecal pellets. These species are small in body size and uniformly pigmented with high metabolic and reproductive rates, which represent adaptations to the highly variable environmental conditions at the soil surface. Different species of earthworms have different life histories, occupy different ecological niches. Loh et al. [3] reported higher cocoon production and weight gain by E. fetida in cattle waste than in goat waste. Gunadi et al. [4] have studied growth, reproduction, and mortality of E. foetida for over a year in solid manure, pig manure, and supermarket waste solids. Worms could not survive in fresh cattle solids, pig solids, fruit wastes, or vegetable wastes. The growth of $\mathrm{E}$. foetida in pig wastes was faster than in cattle solids. Understanding the growth and reproductive efficiency of vermicomposting worms in various substrates is highly essential for effective utilization of earthworms in sustainable waste management system [5-6].

As huge amount of wastes can be managed through more population of earthworms [7] reproductive and growth performance of various species of earthworms in a range of substrates can act as useful biomarkers to measure the efficiency of an earthworm species in vermicomposting or earthworm based biotechnology [8]. Neuhauser et al. [9] have reported that the weight gain by Eisenia fetida is positively correlated with food type. Similarly, Nath et al. $[10,11]$ have also described substrates that provide earthworms with sufficient amount of easily metabolizable organic matter, facilitate growth and reproduction. Hence, in the present study, to see the growth, reproductive biology and life cycle of the vermicomposting earthworms.

\section{Material and Methods}

Life cycle experiments were carried out in the lab Department of Soil Science with average room temperature of $21-28^{\circ} \mathrm{C}$ and 60 to $80 \%$ moisture of the culture media during 15 February to 10 June 2018. For moisture determination, the sample substrates were taken regularly (at 3 days interval) weighed, oven dried at $105^{\circ} \mathrm{C}$ and cooled in desiccators for $1 \mathrm{hr}$ and reweighed. The difference between moist and dried samples were taken and then the moisture content of beddings was adjusted to 60 to $80 \%$ and the temperature was kept within the range of $21-28^{\circ} \mathrm{C}$ throughout the study period [12]. In this experiment was designated as single treatment and two earthworm species (Eisenia fetida and Eudrilus eugeniae) with three replications. For experimentation 500g cowdung was filled in the container. Twenty each earthworm species having individual live weight (225 mg of Eisenia fetida and $284 \mathrm{mg}$ of Eudrilus eugeniae) were released into each experimental container.

\section{Biomass, Maturation and Cocoon Production Date}

Five hatchlings of earthworm species in good health condition were taken from the above containers for reproductive potential determination. The hatchlings were rinsed with distilled water to remove any adhering material, dried briefly on paper towel, weighed on electronic balance and finally introduced in each respective experimental container. Three replicates were established. To monitor the growth and maturation progress weekly, the biomass was measured in batch of earthworm in each container and three phases of the life cycle were observed, Pre-clitelleate (incipient development of the clitellum, identified by appearance of tuber culapubertasis), clitelleate (well-developed clitellum) and regression (loss of the clitellum). At the same time, the first cocoon production date for each worm was also determined. No additional feed was added at any stage during the study period. On the basis of the obtained data on the biomass of the worms other parameters of earthworm such as growth rate or biomass increase rate $(\mathrm{g} /$ earthworm/day), maximum weight achieved, and net weight gain were calculated.

\section{Reproductive Potential (Cocoon Production Rate) Determination}

The experiments were conducted in cylindrical plastic containers. Each container was filled with waste material based on the feeding rate explanation of [13]. Three replicates were prepared for each substrate and worm combination. Two freshly clitellated species, in good health condition, were collected from the stock culture and rinsed with distilled water to remove any adhering material, dried briefly on paper towel, weighed with electronic balance and finally introduced in each container containing. The substrate in treatment container was examined daily in order to determine the onset of cocoon production. Once the cocoons appeared, they were separated by hand sorting, washed lightly in distilled water and counted so as to determine total number of cocoon and the fecundity or reproductive rate (cocoon/worm/day).

\section{Cocoon Incubation Period, Number of Hatchlings and Hatching Success}

To determine the incubation period (time lapse from cocoon formation until the first hatchling emerged in days), hatching success (total number of hatched cocoons), and number of hatchlings per cocoons, fifteen freshly laid cocoons from treatment were taken from the above containers and placed in containers which contained the same material in which their parents were reared. Three replicates were prepared. The beddings were observed daily for the emergence of hatchlings in order to determine the incubation period. As soon as the appearance of hatchling started, they were removed daily using a fine painting brush and counted by hand sorting in order to determine the total number of hatchlings that emerged from a single cocoon. The number of unhatched cocoons was also counted in order to determine the hatching success of cocoons.

\section{Results and Discussion}

\section{Growth Rate of Earthworm Species}

The growth rate of two earthworm species in investigating during the study period is given in Table 1 . The biomass of earthworm species showed progressive raise up to $6^{\text {th }}$ week in E. fetida and $7^{\text {th }}$ week in E. eugeniae. In E. fetida where maximum growth attained, E. fetida achieved their maximum weight achieved $889 \pm 90 \mathrm{mg} /$ worm at a growth rate of $16.3 \pm 0.52 \mathrm{mg} /$ worm/day in the $6^{\text {th }}$ week. In E. eugeniae where maximum growth attained, E. 
eugeniae achieved their maximum weight achieved $1116 \pm 16.4 \mathrm{mg} /$ worm at a growth rate of $17.43 \pm 1.4 \mathrm{mg} /$ worm/day in the $7^{\text {th }}$ week. Regarding the sexual maturity (clitellum development), E. fetida was preclitelated on the second week and mature individual with clitellum totally developed started to emerge on the $3^{\text {rd }}$ week and E. eugeniae was developed in 4 th week of this experiment.

Table 1: Growth parameters of two earthworm species.

\begin{tabular}{|c|c|c|c|c|c|}
\hline $\begin{array}{c}\text { Earthworm } \\
\text { species }\end{array}$ & $\begin{array}{c}\text { Initial weight/ } \\
\text { earthworm (mg) }\end{array}$ & $\begin{array}{c}\text { Maximum } \\
\text { weight achieved/ } \\
\text { earthworm (mg) }\end{array}$ & $\begin{array}{c}\text { Maximum weight } \\
\text { achieved on }\end{array}$ & $\begin{array}{c}\text { Net weight gain/ } \\
\text { earthworm (mg) }\end{array}$ & $\begin{array}{c}\text { Growth rate/ } \\
\text { worm/day (mg) } \\
\text { development } \\
\text { started in }\end{array}$ \\
\hline Eisenia fetida & $196 \pm 69$ & $889 \pm 90$ & $6^{\text {th }}$ week & $686 \pm 22$ & $16.3 \pm 0.52$ \\
\hline Eudrilus eugeniae & $297 \pm 4.1$ & $1116 \pm 16.4$ & $7^{\text {th }}$ week & $819 \pm 12$ & $17.43 \pm 1.4$ \\
\hline
\end{tabular}

Note: All values were introduced as the mean \pm SD (standard deviation).

Edwards et al. [14] and Monroy et al. [15] also reported that rapid pre-reproductive phase of growth, followed by a phase of progressive biomass and growth reduction once sexual maturity was attained. These losses in worm biomass might be associated with the exhaustion of food. As supported by [9] who reported that when E. fetida received food below a maintenance level, it lost weight. The weight reduction was also occurred because the earthworms attained the matured stage. So, they utilized the energy for reproduction purpose such as laying eggs, mating and cocoon formation [6]. Reinecke et al. [16] reported a maximum weight gain for E. eugeniae of $150 \mathrm{mg}$ per week, at $25^{\circ} \mathrm{C}$. Hait and Tare [17] reported that temperature influences the biology of the earthworm by modifying metabolic activity.

Table 2: Rate of cocoon production by two earthworm species.

\begin{tabular}{|c|c|c|c|c|c|}
\hline $\begin{array}{l}\text { Earthworm } \\
\text { species }\end{array}$ & $\begin{array}{l}\text { Cocoon production } \\
\text { started in }\end{array}$ & $\begin{array}{l}\text { Total no. of } \\
\text { cocoons produced }\end{array}$ & $\begin{array}{l}\text { No. of cocoons } \\
\text { produced/ earthworm }\end{array}$ & $\begin{array}{l}\text { No. of cocoons produced/ } \\
\text { earthworm/day }\end{array}$ & $\begin{array}{l}\text { Cocoon production } \\
\text { ceased after }\end{array}$ \\
\hline Eisenia fetida & $6^{\text {th }}$ week & $\begin{array}{c}109 \pm 14.9 \\
\text { (12 weeks) }\end{array}$ & $21.8 \pm 3.0$ & $0.39 \pm 0.05$ & $12^{\text {th }}$ week \\
\hline Eudrilus eugeniae & $7^{\text {th }}$ week & $\begin{array}{c}1016 \pm 31 \\
\text { (9 weeks) }\end{array}$ & $12.61 \pm 1.0$ & $0.21 \pm 0.07$ & $9^{\text {th }}$ week \\
\hline
\end{tabular}

Note: All values were introduced as the mean \pm SD (standard deviation).

\section{Rate of Cocoon Production by Earthworm Species}

In this experiment, E. fetida was started to release cocoon on the 4th week and Eudrilus eugeniae was started to release cocoon on the $5^{\text {th }}$ week (Table 2). The highest total number of cocoon was attained in Eudrilus eugeniae (1016 \pm 31 cocoons at a reproduction rate of $0.21 \pm 0.07$ cocoon/earthworm/day) at 9 weeks and E. fetida $(109 \pm 14.9$ cocoons at cocoon production rate of $0.39 \pm 0.05$ cocoon/earthworm/day) was recorded in this study. Cocoon production ceased after $12^{\text {th }}$ week of Eisenia fetida and Eudrilus eugeniae cocoon production was ceased in $9^{\text {th }}$ week. Giraddi et al. [18] who reported that better hatching success of cocoons that indicate the cocoon viability. E. eugeniae reached sexual maturity in as little as five weeks compared with E. fetida which took 6-8 weeks to produce its first cocoon [19]. Reinecke et al. [16] who reported that E. eugeniae started producing cocoons after 46 days. This is a shorter time than the 6-8 weeks previously quoted for E. fetida [20], and the 51 days reported for E. eugeniae [21].

\section{Incubation Period and Hatching Performance of Cocoons by Earthworm Species}

The incubation period range of two earthworm species were completed in 18-26 days of Eisenia fetida and 12-21 days of Eudrilus eugeniae. The mean number of hatchlings from one cocoon was $3.3 \pm 0.57$ in Eisenia fetida which comparison $2.23 \pm 0.18$ in Eudrilus eugeniae. The cocoons produced generally demonstrated good hatching performance in Eisenia fetida (86.6\%) than Eudrilus eugeniae (75.3\%) (Table 3). Shalabi [22] who reported that the average standard time taken to reach sexual maturity for E. fetida was about 70 days. The result also varied from the result of Venter et al. [23] who recorded 60 days for E. fetida to reach sexual maturity.

Table 3: Incubation period and hatching performance of cocoons by two earthworm species.

\begin{tabular}{|c|c|c|c|c|}
\hline Earthworm & Incubation period (in days) & $\begin{array}{c}\text { Number of hatchlings from one } \\
\text { cocoon }\end{array}$ & $\begin{array}{c}\text { Mean number of hatchlings from one } \\
\text { cocoon }\end{array}$ & Hatching success \\
\hline Eisenia fetida & $18-26$ & $2-4$ & $3.3 \pm 0.57$ & $86.6 \%$ \\
\hline Eudrilus eugeniae & $12-21$ & $2-3$ & $2.23 \pm 0.18$ & $75.3 \%$ \\
\hline
\end{tabular}

Note: All values were introduced as the mean \pm SD (standard deviation). 


\section{Conclusion}

The reproductive ability of Eisenia fetida is higher than Eudrilus eugeniaeit. However, to get accurate knowledge of the full potential of the compost worm as waste processor, it is essential that the life cycle of the worm on waste be studied thoroughly. Eisenia fetida is very suitable as waste decomposer.

\section{References}

1. Reynolds JW, Wetzel MJ (2004) Nomenclatura Oligochaetologica. Supplementum Quartum. A catalogue of names, descriptions and type specimens of the Oligochaeta. Illinois Natural History Survey Special Publication.

2. Bouche MB (1977) Strategies Lombricennes, in Soil organisms as components of ecosystems. (Eds.) Lohm U, Persson, Ecological Bulletins (Stockholm) 25: 122-132.

3. Loh TC, Lee YC, Liang JB, Tan D (2004) Vermicomposting of cattle and goat manures by Eisenia foetida and their growth and reproduction performance. Bioresource Technology 96(1): 111-114.

4. Gunadi B, Edwards CA (2003) The effect of multipleapplications of different organic wastes on the growth, fecundity and survival of Eisenia fetida. Pedobiologia 47(4): 321-330.

5. Appelhof M, Webster K, Buckerfield J (1996) Vermicomposting in Australia and New Zealand. Biocycle 37: 63-66.

6. Jesikha M, Lekeshmanaswamy M (2013) Effect of Pongamia Leaf Medium on Growth of Earthworm (Eudrilus eugeniae) Int J Sci Res Publ 3(1): 2250-3153.

7. Garg VK, Kaushik P (2005) Vermistablization of textile mill sludge spiked with poultry droppings by an epigeic earthworms Eisenia fetida. Biores Technol 96(9): 1063-1071.

8. Suthar S (2007) Vermicomposting potential of Perionyx sansibaricus Perrier in different waste materials. Biores Technol 98(6): 1231-1237.

9. Neuhauser EF, Hartenstein R, Kaplan DL (1980) Growth of the earthworm Eisenia foetida in relation to population density and food rationing. OIKOS 35(1): 93-98.

10. Nath S, Chaudhuri PS (2014) Growth and reproduction of Pontoscolex corethrurus (Muller) with different experimental diets. Tropical Ecology 55(3): 305-312.

ISSN: 2574-1241

DOI: 10.26717/BJSTR.2018.10.002015

Ali S. Biomed J Sci \& Tech Res

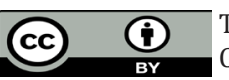

This work is licensed under Creative Commons Attribution 4.0 License

Submission Link: https://biomedres.us/submit-manuscript.php
11. Nath G, Singh K, Singh DK (2009) Effect of different combinations of animal dung and Agro/kitchen wastes on growth and development of earthworm Eisenia fetida. Austr J Basic Appl Sci 3(4): 3553-3556.

12. Chauhan A, Joshi PC (2010) Composting of Some Dangerous and Toxic Weeds Using Eisenia foetida. J Am Sci 6(3): 1-6.

13. Ndegwa PM, Thompson SA, Das KC (2000) Effects of stocking density and feeding rate on vermicomposting of biosolids. Biores Technol 71(1): 5-12.

14. Edwards C, Bohlen PJ (1996) Biology and ecology of earthworms. 3rd Edition, Chapman and Hall publication, London, 4(4): 202-217.

15. Monroy F, Aira M, Gago JA, Dominguez J (2007) Life cycle of the earthworm Octodrilus complanatus (Oligochaeta, Lumbricidae). Compter Rendus Biol 330(5): 389-391.

16. Reinecke A, Viljoen SA, Saayman RJ (1992) The suitability of Eudrilus eugeniae, Perionyx excavates, and Eisenia fetida (Oligocheeta) for vermicomposting in southern Africa in terms of their temperature requirements. Soil Biol Biochem 24(12): 1295-1307.

17. Hait S, Tare V (2011) Optimizing vermistabilzation of waste activated sludge using Vermicompost as bulking material. Waste Manag 31(3): 502-511.

18. Giraddi RS, Gundannavar KP, Tippannavar PS, Sunitha ND (2010) Reproductive Potential of Vermicomposting Earthworms, Eudrilus eugeniae (Kinberg) and Perionyx excavatus (Perrier) as Influenced by Seasonal Factors. Karnataka J Agric Sci 21(1): 38-40.

19. Edwards CA (1988) Breakdown of Animal, Vegetable and Industrial Organic Wastes by Earthworms. In: Edward CA, Neuhauser EF. (eds.), Earthworms in Waste Environ. Manag. SPB Academic Publishing, The Hague, Netherlands p. 21-31.

20. Hartenstein R, Neuhauser EF, Kaplan DL (1979) Reproductive potential of the earthworm Eisenia foetida. Oecologia 43(3): 329-340.

21. Mba CC (1984) Earthworm utilization of Cassava peels (Maninot esculenta). In: Satchell JE (ed) Earthworm Ecology. Chapman \& Hall, London \& New York pp. 315-321.

22. Shalabi M (2006) Vermicomposting of fecal matter as a component of source control sanitation. Doktor-Ingenieurgenehmigte Dissertation, Institute of Wastewater Management and Water Protection, Hamburg University of Technology, Germany pp. 144.

23. Venter JM, Reinecke AJ (1988) The life cycle of the compost worm Eisenia foetida (Oligochaeta). South African Journal of Zoology 23(3): 161-165.

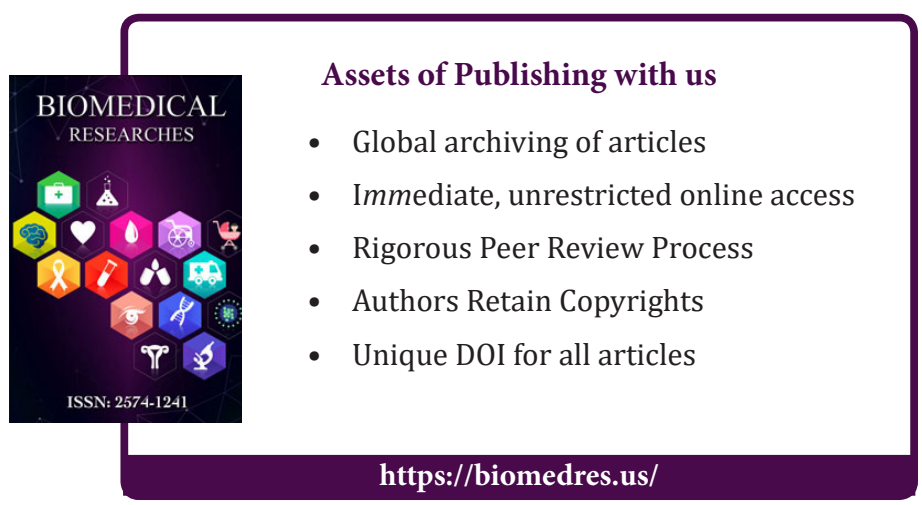

